\title{
THE EFFECT OF VOCABULARY MASTERY AND LEARNING MOTIVATION ON STUDENTS WRITING SKILLS IN NARRATIVE TEXTS
}

\author{
Mega Asriany Dewi ${ }^{1}$ \\ Postgraduate Faculty, English Language Education Program \\ Universitas Indraprasta PGRI, Jakarta \\ e-mail: megaasrianyd@gmail.com ${ }^{1}$
}

\begin{abstract}
This research aims to know the Effects of vocabulary and Learning Motivation on students' writing skills in Narrative text. The population is 150 students. The sample is 84 students. The method is the survey method. Data collecting is taken through a test that consists of a multiplechoice test, questioner, and writing test. The research shows that: 1) there are significant effects of vocabulary mastery and Learning Motivation on students' writing skills in narrative text. That is proved by Sig value $0,000<0,05$ and $\left.F_{o}=10,640 ; 2\right)$ there is a significant effect of vocabulary mastery towards students' writing skills in narrative text. That is proved by Sig value $0,004<0,05$ and $t_{0}=2,930.3$ ). There is a significant effect of Learning Motivation on students' writing skills in narrative text. That is proved by Sig value $0,009<0,05$ and $t_{0}=2,678$.
\end{abstract}

Keywords: vocabulary mastery; learning motivation; writing skill; narrative text.

\section{Introduction}

Learning English is very important because English has become an international language, which is used by most communities in the world. Many countries use English as their second language. Despite the difficulties in studying English, it is worthwhile to study the language because it plays a significant role in almost all fields of life: communication, commerce, economy, politics, education, science, technology. In Indonesia, English is not considered a second language, but English is a foreign language. English is also called the target language that has to be taught teach in schools in today's Indonesian curriculum. Therefore, the student is hoped to increase their ability in English. In recent years, English as a foreign language has been learned by Indonesian learners since they were in Elementary School. At the elementary school, English is taught as a local content subject.

English as the key to international communication and commerce makes it a compulsory subject for students from junior high school up to senior high school. However, those not easy English until now, what happened with a student in these countries, have learned English since elementary school until senior high school or vocational high school cannot English language. One of the problems about this problem is their poor vocabulary mastery, so they are not confident in English speaking. Suddenly, they cannot motivate by the English language. They think the English language is challenging for them because of their poor vocabulary mastery. Vocabulary is one of the essential language components in studying English. Without a prophecy amount of vocabulary, anyone will get trouble speaking, reading, listening, and writing. In other words, the first that to be master for language learner in learning language, especially English, is vocabulary. It means that learning vocabulary is critical, especially for students in senior/vocational high school. They must master English vocabulary and its grammatical rules to make communication with other people. Vocabulary is needed to improve the four language skills, namely listening, speaking, reading, and writing. Without grammar, very little can be conveyed. Without vocabulary, nothing can be conveyed. When we learn about grammar without learning vocabulary, we cannot express anything. Teachers, parents, or observers will easily recognize students with high motivation to learn, and it will also be easy to 


\section{INFERENCE: Journal of English Language Teaching}

Vol. 4, No. 2, August - November 2021

p-ISSN: 2615-8671

e-ISSN: $2615-868 \mathrm{X}$

differentiate them from those with low motivation. Students with high motivation will prefer to read more books, ask many questions to teachers, do the exercises, expose themselves to English language use, try to use their English skills to communicate with others, or happily engage in teaching and learning English. Motivation is a powerful yet tricky beast. People's actions, willingness, and goal or motivation are derived from the word motive in the English language, which is defined as a need that requires satisfaction.

We regularly connect through written communication, which reinforces grammatical structures, idioms, and vocabulary. Writing instruction is a unique method of reinforcing learning. Writing is a type of education in and of itself, and the writing processes and rhetorical environment in which it occurs are critical. So, it is evident that writing is an essential language reinforcing skill and a crucial ability because it becomes a means of learning, discovering, developing, and refining language ability. Through writing, the students become involved with the new language, trying to express their ideas and use eyes, hands, brain constantly as a unique way to reinforce learning.

The teaching-learning process held in a classroom is more concerned with acquiring the other skills. Some factors that because the students to have low proficiency in writing are the students themselves rarely write in English, and the teachers do not facilitate them well to develop their writing skill in classroom activities. In fact, in some cases, writing tends to be a neglected area in English language teaching at school. It seems that competent writing was frequently accepted as the last language skill to be acquired both for native speakers of the language and foreign/second language learners at school. The teachers tend to give the students tasks of making compositions as homework to measure the students' ability since writing is considered a learning activity that takes much time when conducted in a classroom. Since writing is considered a learning activity that takes much time when conducted in a classroom, the student's ability is considered a learning activity.

Writing is one of the English language skills that the students learn in school. In this case, there are some types of texts which students in the school learn. Based on the basic competence of Curriculum 2013, the ten grade students at vocational high school are expected to be able to arrange a short and simple descriptive text, both in the form of spoken and written about people, animals, and things, by considering the purpose, structure of the text and its language elements correctly and appropriate with the context.

\section{Method}

This research will conduct in the vocational High School in Cianjur; the schools that become the research target are SMKN 1 Sukaluyu Cianjur and SMKN 1 Cikalong Kulon in the odd semester of 2019/2020. The reasons for choosing this school were: 1) identify the problem to be researched is found in this school and 2) the location is accessible in terms of time and found and

The research is planned for four months, from October 2019 to January 2020. In this research, three variables consist of two independent variables and one bound variable (dependent variable). Two independent variables are referred to vocabulary mastery (X1) and learning motivation (X2), while a dependent variable is the students' abilities to write narrative essays (Y).

There are several instruments, which are used in viewing the relationship between two independent variables and one dependent variable, namely (a) multiple-choice test to measure the level of knowledge vocabulary mastery, (b) questioner to measure the level of knowledge and engaging English learning, and (c) test essay in the form of a simple design to measure student's ability in terms of narrative essay writing skill.

\section{1) Sample}

Two schools are the sample for this research, namely vocational high school 1 Sukaluyu and vocational high school 1Cikalongkulon in Cianjur regency; after that, 50 students in each selected school become sample; as a result, 100 students in grade ten in the first semester of 2019/2020 academic year to be a sample in this research. The sample of this study is 84 students, by using the Slovin formula.

\section{2) Testing the Hypothesis}


All of the hypothesis tests are fulfilled, and known that data is proper to be tabulated and to be tested by using the hypothesis that has been proposed. The hypothesis is using the partial correlation technique and double correlation and a simple linear quite good. This is indicated by the acquisition value of an average of 81.65

\section{Results and Discussion}

\section{The analyses of writing skills in the narrative text (Y)}

Students' reading comprehension obtained from the test scores of 85 students were selected as a sample. The lowest value is 63 , The highest is 98 , and the average valueis 81.65 , the median is 80.00 , and the mode is 78, and a standard deviation is 7.561. When viewed from the above calculation, it can be said that the students writing skills in the narrative text at vocational high in Cianjur regency are reasonably good. This is indicated by the acquisition value of an average of 81.65 .

\section{1) The analyses of writing skills in the narrative text $(Y)$}

Students' reading comprehension obtained from the test scores of 85 students were selected as a sample. The lowest value is 63 , The highest is 98 , and the average valueis 81.65 , the median is 80.00 , and the mode is 78 , and a standard deviation is 7.561 . When viewed from the above calculation, it can be said that the students writing skills in the narrative text at vocational high in Cianjur regency are quite good. This is indicated by the acquisition value of an average of 81.65.

Table 1

Statistics of writing in narrative text

\begin{tabular}{|c|c|c|c|}
\hline & $\begin{array}{c}\text { Vocabulary } \\
\text { mastery }\end{array}$ & $\begin{array}{c}\text { Learning } \\
\text { motivation }\end{array}$ & $\begin{array}{c}\text { Writing skill in } \\
\text { narrative text }\end{array}$ \\
\hline $\mathrm{N} \quad$ Valid & 84 & 84 & 84 \\
Missing & 0 & 0 & 0 \\
Mean & 80.10 & 77.02 & 81.65 \\
Median & 80.00 & 78.00 & 80.00 \\
Mode & 80 & 67 & 78 \\
Std. Deviation & 8.588 & 8.484 & 7.561 \\
Skewness & -.565 & .070 & .090 \\
Std. Error of Skewness & .263 & .263 & .263 \\
Kurtosis & -.198 & -.830 & -.495 \\
Std. Error of Kurtosis & .520 & .520 & .520 \\
Range & 35 & 34 & 35 \\
Minimum & 60 & 62 & 63 \\
Maximum & 95 & 96 & 98 \\
\hline
\end{tabular}

From the description above, we can see the range between mean score and median score showed that this research data represents the actual condition. The data description can be seen at histogram from the frequency of polygon shown in Diagram 1. 


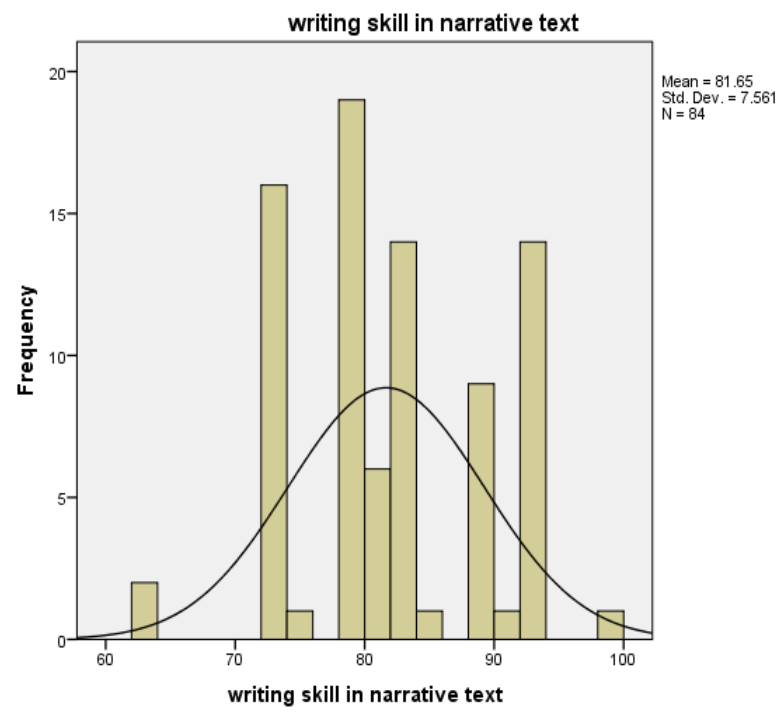

\section{Diagram 1. Histogram of Writing Skill in Narrative Text}

The histogram of frequency polygon can be concluded that the data students writing skill in narrative text vocational high school in Cianjur have a normal distribution.

a) The analyses of Vocabulary Mastery Data (XI)

Students Vocabulary Mastery obtained from the test score of 85 students were selected as a sample. The lowest value is 60 , the highest 95 , and the average value is 80.10 , the median 80.00 , and the mode is 80 , and a standard deviation is 8.588 . Table 1 shows that the student's vocabulary mastery at vocational high school in Cianjur is quite good. This is indicated by the acquisition value of an average of 80.10

\section{b) The analyses of Learning Motivation Data (X2)}

Students learning Motivation obtained from the test scores of 85 students were selected as a sample. The lowest value is 62 , the highest 96 , and the average value is 77,02 , the median 78,00 , and the mode is 67 , and a standard deviation is 8,484 . From Table 1 , above calculation, it can be said the students were learning motivation vocational high school in Cianjur regency good enough. This is indicated by the acquisition of an average score of 77.02, approaching the median value.

Table 2

Normality Test of Data

One-Sample Kolmogorov-Smirnov Test

\begin{tabular}{|c|c|c|c|}
\hline & $\begin{array}{c}\text { Vocabulary } \\
\text { mastery }\end{array}$ & $\begin{array}{l}\text { Learning } \\
\text { motivation }\end{array}$ & $\begin{array}{l}\text { Writing skill in } \\
\text { narrative text }\end{array}$ \\
\hline \multirow{2}{*}{$\begin{array}{c}\text { Normal } \\
\text { Parameters }_{b}^{a} \text {, }\end{array}$} & 84 & 84 & 84 \\
\hline & 80.10 & 77.02 & 81.65 \\
\hline Std. Deviation & 8.588 & 8.484 & 7.561 \\
\hline Absolute & .186 & .131 & .138 \\
\hline Extreme & .115 & .131 & .138 \\
\hline Differences & -.186 & -.125 & -.112 \\
\hline Kolmogorov-Smirnov Z & 1.705 & 1.203 & 1.264 \\
\hline Asymp. Sig. (2-tailed) & .006 & .110 & .082 \\
\hline
\end{tabular}

Table 2 shows the hypothesis that the distribution of the data on this regression analysis follows a normal distribution. The Asymp value shows this. Sig> 0.05. This means that all the data are normally distributed. 
c) Multicollinearity test

Multicollinearity test aims to test whether the regression model found a perfect correlation between the variables free (independents). A good regression model should not occur a perfect correlation between the independent variables. One way to detect the presence of multicollinearity is to look at the tolerance or variance inflation factor (VIF). If tolerance $<0.1$ or VIF $>10$, then multilinear occurs.

Multicollinearity test results in the above table are known that the tolerance $0.932>0.10 \mathrm{r}$ variance inflation factor (VIF) 1.073Thus it can be stated that there is no multicollinearity between vocabulary mastery and learning motivation in this multiple regression analysis.

\section{d) Heteroscedasticity test}

Heteroscedasticity is the error residual observed does not have a constant variance. Heteroscedasticity condition often occurs in cross-section data or data taken from some respondents at a specific time.

One method for detecting the presence of heteroscedasticity is to create a scatter-plot between standardized residual (ZRESID) and standardized predicated Value (Y caps). The picture below showed no change e along with the $\mathrm{Y}$ hat, then declared no heteroscedasticity in errors (error/residual).

\section{e) Normality Test Galat}

Requirements a good regression if the research data follow a normal distribution.

Table 3

Linearity Testing Results from Variable Regression Y on X1 ANOVA Table

\begin{tabular}{|c|c|c|c|c|c|c|c|}
\hline & $\begin{array}{l}\text { Sum of } \\
\text { Squares }\end{array}$ & $\overline{d f}$ & $\begin{array}{c}\text { Mean } \\
\text { Square }\end{array}$ & $\bar{F}$ & Sig. \\
\hline \multirow{5}{*}{$\begin{array}{c}\text { writing } \\
\text { skill in } \\
\text { narrative } \\
\text { text }{ }^{*} \\
\text { vocabular } \\
\text { y mastery }\end{array}$} & \multirow{3}{*}{$\begin{array}{c}\text { Between } \\
\text { Groups }\end{array}$} & (Combined) & 1297.591 & 9 & 144.177 & \multirow{2}{*}{$\begin{array}{l}3.095 \\
14.05\end{array}$} & \multirow{2}{*}{$\begin{array}{l}.003 \\
.000\end{array}$} \\
\hline & & Linearity & 654.614 & 1 & 654.614 & & \\
\hline & & $\begin{array}{l}\text { Deviation } \\
\text { from } \\
\text { Linearity }\end{array}$ & 642.976 & 8 & 80.372 & 1.725 & .107 \\
\hline & Withi & Groups & 3447.398 & 74 & 46.586 & & \\
\hline & & tal & 4744.988 & 83 & & & \\
\hline
\end{tabular}

Based on the data above calculation results obtained, deviation from F0 $=1.725$ and sig $=$ $0.107>0.05$. It has the sense that the variable learning motivation with students writing skills in the narrative text has a linear relationship.

\section{f) Learning regression $X 2$ on $Y$}

Table 4

Linearity Testing Results from Variable Regression Y on X2 ANOVA Table

\begin{tabular}{|c|c|c|c|c|c|c|c|}
\hline & & & $\begin{array}{c}\text { Sum of } \\
\text { Squares }\end{array}$ & $\overline{d f}$ & $\begin{array}{l}\text { Mean } \\
\text { Square }\end{array}$ & $\bar{F}$ & Sig. \\
\hline \multirow{6}{*}{$\begin{array}{l}\text { Writing skill in } \\
\text { narrative text } * \\
\text { Learning } \\
\text { motivation }\end{array}$} & \multirow{3}{*}{$\begin{array}{c}\text { Between } \\
\text { Groups }\end{array}$} & (Combined) & 1317.488 & 15 & 87.833 & 1.743 & .063 \\
\hline & & Linearity & 588.926 & 1 & 588.926 & 11.68 & .001 \\
\hline & & Deviation from & 728562 & 14 & 52040 & 1032 & 433 \\
\hline & & & & & & & \\
\hline & \multicolumn{2}{|c|}{ Within Groups } & 3427.500 & 68 & 50.404 & & \\
\hline & \multicolumn{2}{|c|}{ Total } & 4744.988 & 83 & & & \\
\hline
\end{tabular}


Based on the above calculation results obtained Deviation from linearity with Fo $=1.032$ and sig $=0.433>0.05$, the variable learning motivation by students writing skill in the narrative text has a linear relation.

\section{The test of Research Hypothesis}

1) The Effect of vocabulary mastery (X1) and Learning motivation (X2) towards students writing skill in the narrative text $(Y)$

Hypotheses were tested:

$$
\begin{gathered}
H_{0}: \beta_{y 1}=\beta_{y 2}=0 \\
H_{1}: \beta_{y 1} \neq 0, \text { and } \beta_{y 2} \neq 0
\end{gathered}
$$

This means:

$H_{0}$ : there is no effects between vocabulary mastery and learning motivation towards students writing skills in narrative text

$H_{1}$ : there are effects between vocabulary mastery and learning motivation towards students writing skills in narrative text.

Tabel 5

Calculation result significance testing regression coefficients variable XI

and $\mathrm{X} 2$ to $\mathrm{Y}$

ANOVA $^{\mathrm{a}}$

\begin{tabular}{|cc|c|c|c|c|c|}
\hline \multirow{2}{*}{ Model } & Sum of & Df & Mean Square & F & Sig. \\
& & Squares & & & & \\
\hline \multirow{4}{*}{1} & Regression & 987.220 & 2 & 493.610 & 10.640 & $.000^{\mathrm{b}}$ \\
& Residual & 3757.768 & 81 & 46.392 & & \\
& Total & 4744.988 & 83 & & & \\
\hline
\end{tabular}

a. Dependent Variable: writing skill in narrative text

b. Predictors: (Constant), Learning motivation, vocabulary mastery

Tabel 6

Coefficientsa

\begin{tabular}{|c|c|c|c|c|c|}
\hline \multirow{2}{*}{ Model } & \multicolumn{2}{|c|}{$\begin{array}{c}\text { Unstandardized } \\
\text { Coefficients }\end{array}$} & $\begin{array}{c}\text { Standardized } \\
\text { Coefficients }\end{array}$ & \multirow{2}{*}{ T } & Sig. \\
\cline { 2 - 4 } & B & Std. Error & Beta & & \\
\hline \multirow{2}{*}{$1 \quad \begin{array}{c}\text { (Constant) } \\
\text { vocabulary } \\
\text { mastery }\end{array}$} & 41.672 & 8.701 & & 4.790 & .000 \\
& .264 & .090 & .300 & 2.930 & .004 \\
$\begin{array}{c}\text { Learning } \\
\text { motivation }\end{array}$ & .244 & .091 & .274 & 2.678 & .009 \\
\hline
\end{tabular}

a. Dependent Variable: writing skill in narrative text

From Tabel 5, it can be stated that there are any significant effects of vocabulary mastery and learning motivation seriously towards students writing skills in narrative text. This is towards the acquisition of the sig. $0.000<0.05$ and $\mathrm{F}_{\mathrm{o}}=10.640$. Meanwhile, the multiple regression equation can be expressed by $\mathrm{Y}=41.672+0.264 \mathrm{X} 1+0.244 \mathrm{X} 2$. It has the sense that the increase in the variable scores and vocabulary mastery and learning motivation contributed $0.264 \mathrm{X} 1$ and X2 to 0.244 by the variable students writing skill in narrative text. Table 5 also explains that together variable learning motivation and vocabulary mastery contributed $20.8 \%$ Of the variable students writing skills in narrative text. 
2) The effect of vocabulary mastery (X1) of the students writing skill in the narrative text $(Y)$

Hypotheses were tested:

This means:

$$
\begin{gathered}
H_{0}: \beta_{y 1}=0 \\
H_{1}: \beta_{y 1} \neq 0
\end{gathered}
$$

$H_{0}$ : There is no effect between vocabulary mastery towards students writing skills in narrative text $H_{1}$ : There is an effect between vocabulary mastery towards students writing skills in narrative text.

From the table coefficient. It can be stated that there is a significant effect of vocabulary mastery on students writing skills in narrative text. This is towards the acquisition of the sig. $0.004<0.05$ and $t_{0}=$ 2.930. The formula can express the variable contribution towards vocabulary mastery students writing skill in narrative text:

$$
\begin{gathered}
\mathrm{KD}=\text { Nilai } \beta_{x y 1} \times \text { partial correlation }\left(r_{x 1 y}\right) \times 100 \% \\
\mathrm{KD}=0.300 \times 0.310 \times 100 \%=9.3 \%
\end{gathered}
$$

From the above calculation can be stated the contribution of vocabulary mastery in influence students writing skill is $9.3 \% /$

\section{3) The effect of Learning Motivation (X2) of the students writing skill in the narrative text ( $Y$ )}

Hypotheses were tested:

This means:

$$
\begin{gathered}
H_{0}: \beta_{y 2}=0 \\
H_{1}: \beta_{y 2} \neq 0
\end{gathered}
$$

$H_{0}$ : There is no effect between learning motivation towards students writing skills in narrative text.

$H_{1}$ : There is an effect between learning motivation towards students writing skills in narrative text.

From the table coefficient. It can be stated that there is a significant effect of learning motivation towards students writing skills in narrative text. This is proved by the acquisition of the sig $0.009<0.05$ and to $=2.678$. The formula can express the variable contribution learning motivation of the students writing skills.

$$
\begin{gathered}
\mathrm{KD}=\text { Nilai } \beta_{x 2 y} \times \text { partial correlation }\left(r_{x 2 y}\right) \times 100 \% \\
\mathrm{KD}=0.274 \times 0.284 \times 100 \%=7,8 \%
\end{gathered}
$$

The above calculation can be stated that the contribution of learning motivation in improving student's writing skills in the narrative text is $7.8 \%$.

\section{The effects of vocabulary mastery (X1) and Learning motivation (X2) jointly towards students writing} skills in the narrative text $(Y)$.

The above study concludes that vocabulary mastery and learning motivation have a positive effect on improvements of students' writing skills in narrative text Vocational High school in Cianjur regency. This implies that vocabulary mastery and learning motivation significantly influence students' writing skills in narrative text in vocational high school in Cianjur regency.

Writing is one's skill that a student at a vocational high school should master. Writing means understanding the text in learning, and learning plays an essential role in writing skills other language skills. Writing nowadays is not learned apart from other skills. It should be integrated and put in the whole context. To achieve this, language elements such as vocabulary and an appropriate writing strategy or model are required. Writing without being influenced by many factors. Those factors come from either inside or outside the individual or learner, both related to linguistic and nonlinguistic factors. 
Students with high motivation to learn English will better prepare themselves to engage in teaching and learning in the classroom. Teachers, parents, or observers will also be easy to differentiate them from one with low motivation. Students with high motivation will prefer to read more books and write the story, ask many questions to teachers, do the exercises, expose themselves to the English language using, use their English skills to communicate with others, or happily engage in the process of teaching and learning English. Meanwhile, students with low motivation usually have no strong will to engage in teaching and learning English. They rarely ask questions even though they do not understand the subject. They will have to be forced by the teacher or parents to read the book, write a story, do the exercises, and do the teacher's tasks. Students with low motivation usually assume English as a complex or even challenging subject to be learned. Another factor influencing writing success is linguistic factors such as knowledge of vocabulary, punctuation, and other parts of the language.

\section{The effect of Vocabulary mastery (X1) towards students writing in the narrative text (Y)}

From research and theory, vocabulary mastery has a positive influence on the increase in students writing narrative text vocational high school in Cianjur regency. The mastery of vocational high school vocabulary has a significant influence on the improvement of students writing narrative text vocational high school in Cianjur regency.

Vocabulary mastery can help the students have good writing skills, speaking, and reading. The students that have enough vocabulary will not understand the meaning of words, so that they are easier to know the meaning of the text. To get the meaning of a text and to writing text, the special is narrative text. The students should know the structure, grammar, and vocabulary. Vocabulary does not mean that the learners only memorize the words and their meanings and how they are contracted and use language.

Vocabulary is an important thing and one aspect that the students in learning English should master. Mastering vocabulary is required to make the students easier in the text English. In other words, a lack of vocabulary in learning English will cause difficulties in the text. It means that English teachers should have some techniques or good teaching and English. Thornbury (2007:159) stated, " one to timetable plenty of time for vocabulary focused activities. Teachers can take heart from recent research development that suggests that a heavy concentration on vocabulary acquisition, especially in the early stage of learning, is a prerequisite for later proficiency in the language.

Vocabulary plays an essential part in language use. It dramatically impacts the students when they want to convey and share their opinion by oral and written. The students can speak fluently and have good writing if they have some vocabulary. It is also one of the factors to master English as a foreign language. Thornbury (2007:22) "a good part of vocabulary acquisition has to be incidental. Incidental learning is facilitated through exposure to language input, in the form of extensive writing".

In other words, vocabulary mastery is one factor that leads the students in mastering English successfully besides the other factors like English skills, reading, writing, speaking, listening, age, motivation

\section{The effects of Learning motivation (X2) towards students writing in the narrative text (Y)}

The above studies concluded that learning motivation positively affects the improvement of students writing in narrative text public vocational high school in Cianjur regency. This implies that learning motivation has significant influences on the improvement of students writing in narrative text public vocational high school in Cianjur regency.

The importance of good relations between teachers and students. They notice what the effects can be if the relations function positively and the negative ones if the relations are poor. The teachers' relations to his or her students can influence whether the students will want to try to develop and learn more. Essential factors for the quality of the relations between the student and the teacher are that the students can trust the teacher, respect him or her and that the communication goes well. There is not so much written about learners' attitudes to their relationship with their teacher.

Arends (2009:143) states that "the motivation toward influence can be seen in those students who strive to have more control over their learning and in those teachers who strive to have a larger say in the way schools are run." Motivation is what makes people try and spend energy on what they do to fulfill their needs. Motivation also means moving people to do things because they have the drives to do it. Esti (2009:28) states, "one of the teacher's most important roles is motivation." 
To meet the needs of the individual, which drives him to do something with great motivation. Learning motivation is all of the inner and psychological drives that push or prompt students to study and learn, which guarantees the continuity of learning activities, which gives the goal to be achieved.

\section{Conclusions}

There are significant effects of vocabulary mastery and learning motivation on students' writing skills in the narrative text at state vocational high school in Cianjur regency. It is proved by the score of Sig $0.000<0.05$ and $F_{0}=10.640$. Taken together, vocabulary mastery and learning motivation contributed $20.8 \%$ of the variable students writing in narrative text. Next, there is a significant effect of vocabulary mastery towards student writing in the narrative text at state vocational high school in Cianjur regency. This is proved by the value of the sig $0.004<0.05$ and $=t_{o} 2.930$, and variable vocabulary mastery contributed $9.3 \%$ to improve students writing in narrative text. Finally, there are significant learning motivation effects towards students writing in the narrative text at state vocational high school in Cianjur regency. This is proved by the value of the sig $0.009<0.05$ and $t_{o}=2.678$, variable learning motivation contributed $7.8 \%$ to improve students writing in narrative text.

\section{References}

Aronson. (2001:5). Role of Motivation. New York: Pearson Education. Berge. (2000:7). Learning Motivation. New York: Pearson Education.

Brown, D. H. (2000:7). Principle of Language Learning and Teaching. New York: Pearson Education, Inc.

Caroline. (2005). Vocabulary Mastery. New York: Pearson Education.

Chujo. (2004:37). Principle Of Vocabulary. New York: Pearson Education.

Crystal. D. (2003). Vocabulary Mastery. New York: Pearson Education.

Dewi, K. (2012). Students' Ability in Writing Narrative Texts in the form of an Anecdote". Malang.

Driscoll, J. (2000:3). Learning. New York: Pearson Education.

Ferlazzo. (2001). Motivation for children. New York: Pearson Education.

Hamzah. (2001). Learning Motivation. Yogyakarta.

Harmer, J. (2000). Motivation for learning. New York: Pearson Education.

Hornby. (2000). Vocabulary Mastery. New York: Pearson Education.

Kimble. (2000). Learning English. New York: Pearson Education.

Kirszhen, L. G. \& Mandell, S. R. (2008). Focus on writing paragraphs and essays. Boston: Bedford/.

Maharani, I. (2007). How to Write Effectively. Yogyakarta: Citra Aji Parama.

Meyers. (2005). Writing Skill. New York: Pearson Education.

Nunan, D. (2003). Practical English Language Teaching. New York: McGraw-Hill.

Nunan, D. (200). Vocabulary mastery. New York.: McGraw-Hill.

Pardiyono. (2007). Teaching Genre-Based Writing. Yogyakarta.

Penny. (2002). Learning. Yogyakarta.

Richard. (2002). Teaching writing skills. New York: Prentice-Hall.

Santrock. (2000). Motivation. New York: Prentice-Hall.

Schmitt. (1997). Vocabulary Mastery. New York: Prentice-Hall.

Sino. (2005). English Teaching. New York: Prentice-Hall.

Shunk. (2013). Motivation is Energy. New York: Prentice-Hall.

Slovin. (2011). Analysis Data. New York: Prentice-Hall.

Swan. (2000). Grammar Mastery. New York: Prentice-Hall.

Ur. (2000). Grammar Mastery. New York: Prentice-Hall.

Woolfolk. (2001). Motivation. New York: Prentice-Hall.

Wilkins. (2003). Grammar Mastery. New York: Prentice-Hall. 